\title{
Impact of the Encapsulation Process by Spray- and Freeze-Drying on the Properties and Composition of Powders Obtained from Cold-Pressed Seed Oils with Various Unsaturated Fatty Acids
}

\author{
Dorota Ogrodowska ${ }^{1}$, Matgorzata Tańska ${ }^{1, *}$, Waldemar Brandt ${ }^{2}$, Sylwester Czaplicki ${ }^{1}$ \\ ${ }^{1}$ Department of Plant Material Processing and Chemistry, Faculty of Food Science, \\ University of Warmia and Mazury, Plac Cieszyński 1, 10-726 Olsztyn, Poland \\ ${ }^{2}$ Department of Dairy Science and Quality Management, Faculty of Food Science, \\ University of Warmia and Mazury, Plac Cieszyński 1, 10-726 Olsztyn, Poland
}

Key words: cold-pressed oils, encapsulation, tocopherols, sterols, fatty acids

The aim of this study was to determine the influence of encapsulation methods on fatty acid composition and content of bioactive compounds in cold-pressed oils. Rape, flax, and safflower seed oils (10.2\%) were mixed with water (70.0\%) and wall components (19.8\%) to obtain emulsions, which were then subjected to spray- and freeze-drying. Surface and total oil contents, and changes in contents of fatty acids, sterols, and tocopherols were compared in powders and natural oils.

The spray-drying was a more effective encapsulation method compared to the freeze-drying. Fatty acid composition of the oils was quite stable during the encapsulation process. Sterol degradation was high and only $35-40 \%$ of these compounds were determined in powders. In turn, tocopherol losses were dependent both on the encapsulation method and oil type. The encapsulation by freeze-drying allowed the retention of almost all tocopherols of cold-pressed flax and safflower seed oils.

\section{INTRODUCTION}

Cold-pressed plant oils are used mainly by the pharmaceutical industry as a raw material for the production of dietary supplements, while their application is limited in the food industry. These oils constitute, first of all, an element of "slow food" [Miele \& Murdoch, 2002], which is due to their poor storage stability, related to a high content of polyunsaturated fatty acids, like particularly in flax and safflower seed oils [Dorni et al., 2018; Khattab \& Zeitoun, 2013; Tańska et al., 2016].

Cold-pressed oils obtained from such raw materials as rape, flax or safflower seeds are considered to be valuable edible fats from a nutritional point of view. Their value is a result of, among others, a high content of unsaturated fatty acids, oleic acid in rape seed oil (up to 60\%), linoleic acid in safflower seed oil (up to 80\%), and $\alpha$-linolenic acid in flax seed oil (up to 60\%) [Ghazani et al., 2014; Khalid et al., 2017; Tańska et al., 2016]. A beneficial effect of fatty acids of the rape seed oil on the blood lipid profile consists in reducing the concentration of total cholesterol and the low-density lipoprotein (LDL) fraction, without any effect on the concentration of the high-density lipoprotein (HDL) fraction [Nguemeni et al., 2010]. Additionally, results obtained by Nguemeni et al. [2010] support the hypothesis that diet supplementation with rape seed

\footnotetext{
* Corresponding Author: E-mail: m.tanska@uwm.edu.pl (M. Tańska) are transformed into particles. Another popular method used

oil can enhance the treatment of ischemic stroke. $\alpha$-Linolenic acid, which belongs to the $n-3$ family (flax seed oil is a good source of this acid), may help protect against certain infections and in treating conditions including ulcers, migraine headaches, attention deficit/hyperactivity disorder, eating disorders, preterm labour, emphysema, psoriasis, glaucoma, Lyme disease, lupus, and panic attacks [Harper et al., 2006]. The health-promoting properties of the above-mentioned cold-pressed oils are also affected by the native bioactive components they contain, such as: sterols (up to $835 \mathrm{mg} / 100 \mathrm{~g}$ in rape seed oil), tocopherols (up to $60 \mathrm{mg} / 100 \mathrm{~g}$ in flax seed oil), carotenoids (up to $28 \mathrm{mg} / 100 \mathrm{~g}$ in rape seed oil), squalene (up to $4 \mathrm{mg} / 100 \mathrm{~g}$ in flax seed oil), and polyphenols (up to $14 \mathrm{mg} / 100 \mathrm{~g}$ in safflower seed oil) [Ben Moumen et al., 2015; Ghazani et al., 2014].

The use of plant oils in the food industry can be increased by the application of the encapsulation process, which allows extending the oxidative stability of the core of the capsule and guarantees the controlled release of substances from the capsule during the technological process [Aksoylu \& Günç Ergönül, 2017]. The most popular method of oil encapsulation is the spray-drying. It is considered to be an optimal solution for oils because it allows for the transformation of emulsion into powder, simultaneously preserving its valuable properties. Because of the large surface area of the droplets, water evaporates almost immediately and the droplets 
to prepare powdered oils is encapsulation by freeze-drying. It requires a much longer time but can be done at a very low temperature. During this process, water is frozen, followed by its removal from the sample, initially by sublimation (primary drying) and then by desorption (secondary drying) [Ogrodowska et al., 2017].

Oil in a powdered form can be applied as a functional supplement to dairy products [Wang et al., 2011], bakery products [Gallardo et al., 2013], and fruit and vegetable products [Donsì et al., 2011]. Although encapsulated oils are easier to apply in food products and more resistant to oxidative changes than the cold-pressed oils, there are still few studies that explain the effect of the encapsulation on the native oil components such as unsaturated fatty acids and bioactive compounds.

Our previous work [Ogrodowska et al., 2019] showed that the encapsulation by spray- and freeze-drying had a significant impact on the content of bioactive compounds and oxidative stability of encapsulated bio-oils from evening primrose, borage, and blue weed seeds. We showed that despite the lower process efficiency, the encapsulation by freeze-drying would be more recommended for evening primrose seed oil. In turn, the encapsulated borage and blue weed oils should be produced by spray-drying. We hypothesized that the differences observed were connected to the initial chemical composition of the bio-oils used. Little is known, however, on this kind of a relationship. Generally, previous studies have focused on the physical properties of powders obtained with different encapsulation methods or under different process conditions [Bakry et al., 2016].

In this work, we compared the influence of the most popular encapsulation methods (spray- and freeze drying) on the effectiveness of the encapsulation process and losses of sterols and tocopherols in powders obtained from cold-pressed oils with various unsaturated fatty acid composition.

\section{MATERIALS AND METHODS}

\section{Materials}

Three types of cold-pressed plant oils were investigated in this study. Seeds of rape, flax, and safflower were from "Szarłat" company (Łomża, Poland). The oils were produced by pressing the raw material on a IBG Monforts \& Reiners, Komet CA59G (Nürnberg, Germany) laboratory expeller equipped with a nozzle gaving $4 \mathrm{~mm}$ in diameter. The oils were purified by centrifugation on a centrifuge (type $5810 \mathrm{R}$, Eppendorf AG, Hamburg, Germany) operated at 15,000×g. Whey protein concentrate was purchased from"Ostrowia" company (Ostrów Mazowiecka, Poland). Maltodextrin (DE 14-22) and guar gum were purchased from Edpol Food \& Innovation Company (Łomża, Poland).

\section{Emulsification process}

The composition of emulsions was the same for all samples: $19.8 \%(w / w)$ of wall materials (maltodextrin $15.4 \%$, whey protein concentrate $3.9 \%$, and guar gum $0.5 \%), 10.2 \%(w / w)$ of oil, and $70 \%(w / w)$ of water. The proportion of wall materials and oil loading were established based on the work of Ogrodowska et al. [2017]. The oils were blended with aqueous solutions of wall materials at $9,000 \mathrm{rpm}$ for $120 \mathrm{~s}$ at $40^{\circ} \mathrm{C}$ using Thermomix (Vorwerk, Wuppertal, Germany). Then, emulsions were further homogenized at 240 bar (I step) and 40 bar (II step) using a high-pressure laboratory valve homogenizer (Panda 2K, GEA Niro Soavi, Parma, Italy).

\section{Emulsion drying process}

The spray-dried powders were prepared using a pilot-plant spray dryer (A/S Niro Atomizer, Copenhagen, Denmark) with disc having $110 \mathrm{~mm}$ in diameter as a spraying mechanism at $6400 \mathrm{rpm}$. The emulsion was pumped into a spray dryer chamber at a constant feeding speed. The inlet temperature was set at $130^{\circ} \mathrm{C}$, whereas the outlet temperature at $90^{\circ} \mathrm{C}$. The feed flow rate was $77 \mathrm{~mL} / \mathrm{min}$ and the air flow rate was approx. $400 \mathrm{~kg} / \mathrm{h}$.

Freeze-dried powders were prepared using a lyophilizer (Cryolizer Freeze Dryer type B-64, New Brunswick Scientific Co., Inc., New Brunswick, NJ, USA). The emulsions were put into aluminium pans and frozen at $-20^{\circ} \mathrm{C}$ for $24 \mathrm{~h}$. Then, the emulsions were lyophilized, with an ice condenser set at $-50^{\circ} \mathrm{C}$ at a pressure of 0.12 mbar and freeze-drying time reaching $72 \mathrm{~h}$.

\section{Physical characterization of emulsions}

Immediately after preparation, $50 \mathrm{~mL}$ of an emulsion sample was transferred to a graduated cylinder of $50 \mathrm{~mL}$, sealed, and stored at $25^{\circ} \mathrm{C}$ for $24 \mathrm{~h}$. The emulsion stability was evaluated by the phase separation observed throughout $24 \mathrm{~h}$ and expressed as \% of upper phase separation.

The viscosity of the emulsions was measured using a Brookfield RV DV-II+ Pro Extra rheometer (AMETEK Brookfield, Middleboro, MA, USA) equipped with an RV-3 stainless steel spindle (disc with a diameter of $34.69 \mathrm{~mm}$ and a height of $1.65 \mathrm{~mm}$ ). Measurements $(100 \mathrm{~mL}$ of emulsion) were done at $25^{\circ} \mathrm{C}$ by a linear increase in shear stress from 0.01 to $1.64 \mathrm{~Pa}$. Viscosities are given as the average viscosity of the linear part of the plot of shear stress versus viscosity and are expressed in $\mathrm{mPa} \cdot \mathrm{s}$.

Droplet size of emulsions was measured using a Mastersizer 3000 particle size analyzer (Malvern Instruments, Ltd., Worcestershire, UK). Emulsion droplets were suspended in recirculating water $(3,000 \mathrm{rpm})$, reaching an obscuration of $15-18 \%$. Measurements were carried out at $25^{\circ} \mathrm{C}$ and emulsion droplet size was expressed as Sauter mean diameter $\mathrm{D}(4,3)$.

\section{Characterization of encapsulation process effectiveness}

The content of surface oil was determined in the oils with the washing method [Ogrodowska et al., 2017]. The surface oil was extracted three times with hexane for $5 \mathrm{~min}$, filtered, and evaporated to dryness in the R-210 type rotary evaporator (Büchi Labortechnik AG, Flawil, Switzerland) under an $\mathrm{N}_{2}$ stream.

The total oil content in the powders was determined according to the method described by Ogrodowska et al. [2017]. The total oil was extracted with a $2: 1(\mathrm{v} / \mathrm{v})$ chloroform:methanol mixture, then the chloroform phase was isolated and evaporated to dryness in the R-210 type rotary evaporator (Büchi Labortechnik AG) under an $\mathrm{N}_{2}$ stream.

The process efficiency (PE) of encapsulated oil production was determined as the ratio between the oil covered 
by wall material and the total oil content in the powder [Kaushik et al., 2015]. The content of oil covered by the wall material was computed from the difference between total oil content and surface oil content in the powder whose values were determined as described above.

\section{Morphological characterization of powders}

The morphology of the powders was analyzed using scanning electron microscopy (SEM). The Quanta 200 SEM (FEI Company, Hillsboro, OR, USA) was applied to acquire images of the powder samples. Each powder sample was placed on double-sided adhesive carbon tabs, mounted on SEM tubs, and coated with palladium in a sputter coater. Then, the coated sample was analyzed using the SEM operating an accelerating voltage of $30 \mathrm{kV}$ with $800 \times$ (spray-dried sample) or $100 \times$ (freeze-dried sample) magnifications.

\section{Fatty acid composition of oils and powders}

Fatty acid composition was analyzed in the total oil extracted with a 2:1 ( $\mathrm{v} / \mathrm{v})$ chloroform:methanol mixture.

Fatty acid esters were prepared according to the procedure described in a work of Zadernowski \& Sosulski [1978]. The fatty acids were methylated by heating their solution in a chloroform:methanol:sulfuric acid mixture (100:100:1, v/v/v) at $70^{\circ} \mathrm{C}$ for $2 \mathrm{~h}$. Fatty acids methyl esters were analyzed using a GC-MS QP2010 PLUS system (Shimadzu, Kyoto, Japan) equipped with a BPX70 capillary column $(25 \mathrm{~m} \times 0.22 \mathrm{~mm} \times$ $0.25 \mu \mathrm{m}$; SGE Analytical Science, Victoria, Australia). Helium was used as the carrier gas with a flow rate of $0.9 \mathrm{~mL} / \mathrm{min}$. The temperatures were as follows: the injector $-230^{\circ} \mathrm{C}$, the column was programmed in the range from $150^{\circ} \mathrm{C}$ to $250^{\circ} \mathrm{C}$, interface of $\mathrm{GC}-\mathrm{MS}-240^{\circ} \mathrm{C}$, the ion source $-240^{\circ} \mathrm{C}$, and the electron energy was $70 \mathrm{eV}$. Individual fatty acids methyl esters were identified on the basis of their retention times and mass spectra, and results were expressed as the percentage $(w / w)$ of each fatty acid in total fatty acids based on their peak areas.

\section{Content of bioactive compounds in oils and powders}

Bioactive compounds were analyzed in the total oil extracted with a 2:1 $(v / v)$ chloroform:methanol mixture.

The content of sterols was determined according to the procedure described in the work of Roszkowska et al. [2015]. The oil samples were dissolved in hexane, and a $5 \alpha$-cholestane solution was added as an internal standard. The oil sample with the $5 \alpha$-cholestane (internal standard) hexane solution was saponified in $2 \mathrm{M} \mathrm{KOH}$ in a methanolic solution at $70^{\circ} \mathrm{C}$ for $30 \mathrm{~min}$. Sterols were extracted three times with diethyl ether. The collected extracts were evaporated to dryness in the R-210 type rotary evaporator (Büchi Labortechnik AG) under an $\mathrm{N}_{2}$ stream. Then, the residue was re-dissolved in pyridine and $\mathrm{N}, \mathrm{O}$-bis-(trimethylsilyl)trifluoroacetamide (BSTFA) with $1 \%(w / w)$ trimethylchlorosilane (TMCS), and derivatized at $60^{\circ} \mathrm{C}$ for $60 \mathrm{~min}$. The mixture was re-dissolved in heptane and analyzed using a GC-MS QP2010 PLUS system (Shimadzu, Kyoto, Japan) equipped with a ZB-5ms capillary column $(30 \mathrm{~m} \times 0.25 \mathrm{~mm} \times 0.25 \mu \mathrm{m}$; Phenomenex, Torrance, CA, USA). Helium was used as the carrier gas with a flow rate of $0.9 \mathrm{~mL} / \mathrm{min}$. The temperatures were as follows: the injector $-230^{\circ} \mathrm{C}$, the column was programmed in the range from $70^{\circ} \mathrm{C}$ to $310^{\circ} \mathrm{C}$, the interface of $\mathrm{GC}-\mathrm{MS}-240^{\circ} \mathrm{C}$, the ion source $220^{\circ} \mathrm{C}$, and the electron energy was $70 \mathrm{eV}$. The sterols were identified on the basis of their retention times and mass spectra. Quantitative analysis of individual compounds was made based on the internal standard method with the use of $5 \alpha$-cholestane.

The content of tocopherols was determined according to the procedure described in the work of Czaplicki et al. [2011]. The oil samples diluted in hexane were analyzed using an Agilent Technologies 1200 series apparatus with a fluorescence detector (Santa Clara, CA, USA). Individual compounds were separated on a LiChrospher Si60 column $(250 \mathrm{~mm}$ $\times 4 \mathrm{~mm}, 5 \mu \mathrm{m}$; Merck, Darmstadt, Germany) with the use of $0.7 \%(v / v)$ iso-propanol solution in $n$-hexane as a mobile phase and the flow rate set at $1 \mathrm{~mL} / \mathrm{min}$. The fluorescence detector was used with excitation and emission wavelengths of $296 \mathrm{~nm}$ and $330 \mathrm{~nm}$, respectively. Quantitative analysis of individual tocopherols was done based on external calibration curves prepared for $\alpha$-, $\gamma$-, and $\delta$-tocopherol. The sum of $\beta$ - and $\gamma$-tocopherols was calculated as $\gamma$-tocopherol.

\section{Statistical analysis}

The results obtained were analyzed statistically using Statistica 12.0 PL software (StatSoft, Kraków, Poland). The differences between mean values were determined using the analysis of variance (ANOVA) with Tukey's test at $\mathrm{p} \leq 0.05$ significance level.

\section{RESULTS AND DISCUSSION}

\section{Characteristics of encapsulation effectiveness of cold- -pressed oils}

Table 1 presents the contents of surface oil and total oil, and process efficiency for cold-pressed oils encapsulated using the spray- and freeze-drying methods. The samples obtained as a result of spray-drying, regardless of oil type, had a much lower content of surface oil $(2.91-5.30 \%, w / w)$ compared to those obtained by freeze-drying (10.25-10.76\%, $w / w)$. The total oil content in the powders obtained as a result of spray-drying ranged from $28.97 \%(w / w)$ for rapeseed oil to $29.85 \%(w / w)$ for safflower seed oil. In turn, the freeze-dried samples had by $1-3 \%$ lower content of total oil. The process efficiency for the powders obtained as a result of spray-drying ranged from $82.23 \%$ to $89.97 \%(w / w)$. A high content of surface oil and a similar content of total oil in the samples encapsulated by freeze-drying in comparison to those obtained by spray-drying resulted in the low efficiency of their encapsulation process $(62.66-64.86 \%, w / w)$.

The results obtained correspond to the data presented by other authors. Gallardo et al. [2013], who spray-dried emulsions composed of flax seed oil and Arabic gum or its mix with maltodextrin and whey protein isolate, determined the surface oil and the total oil contents, as well as the process efficiency in the following ranges: 1.9-2.7\% $(w / w), 22.1-32.9 \%(w / w)$ and $87.8-91.4 \%(w / w)$, respectively. In turn, the use of maltodextrin and methyl cellulose for flax seed oil encapsulation brought about an increase in the surface oil content $(24.5 \%$, $w / w)$, which resulted in a low PE $(25.5 \%, w / w)$. The surface 
TABLE 1. Surface and total oil contents, and efficiency of the encapsulation process of cold-pressed oils.

\begin{tabular}{lccc|c}
\hline Type of cold-pressed oil & Emulsion drying method & Surface oil content $(\%, w / w)$ & Total oil content $(\%, w / w)$ & Process efficiency $(\%, w / w)$ \\
\hline \multirow{2}{*}{ Rape seed oil } & SD & $2.91 \pm 0.09^{\mathrm{bC}}$ & $28.97 \pm 0.07^{\mathrm{aB}}$ & $89.97 \pm 0.30^{\mathrm{aA}}$ \\
& FD & $10.57 \pm 0.24^{\mathrm{aA}}$ & $28.64 \pm 0.10^{\mathrm{bA}}$ & $63.08 \pm 0.95^{\mathrm{bA}}$ \\
\hline \multirow{2}{*}{ Flax seed oil } & SD & $3.68 \pm 0.03^{\mathrm{bB}}$ & $29.74 \pm 0.03^{\mathrm{aA}}$ & $87.63 \pm 0.25^{\mathrm{aB}}$ \\
& FD & $10.76 \pm 0.40^{\mathrm{aA}}$ & $28.82 \pm 0.54^{\mathrm{bA}}$ & $62.66 \pm 0.68^{\mathrm{bA}}$ \\
\hline \multirow{2}{*}{ Safflower seed oil } & SD & $5.30 \pm 0.17^{\mathrm{bA}}$ & $29.85 \pm 0.58^{\mathrm{aA}}$ & $82.23 \pm 0.92^{\mathrm{aC}}$ \\
& FD & $10.25 \pm 0.47^{\mathrm{aA}}$ & $29.18 \pm 0.18^{\mathrm{bA}}$ & $64.86 \pm 1.40^{\mathrm{bA}}$ \\
\hline
\end{tabular}

Mean values in columns, for each type of oil separately (lowercase letters) and for each emulsion drying method separately (uppercase letters), denoted by the same letter do not differ statistically significantly at $\mathrm{p}>0.05$ (Tukey test). SD - spray-drying, FD - freeze-drying.

oil content $(4.73-5.57 \%, w / w)$, similar to the values presented in our study, was also determined by Goyal et al. [2015], who used lactose, milk proteins, and sodium caseinate to encapsulate refined flax seed oil by spray-drying. In turn, Chang et al. [2016] obtained a broad range of surface oil contents for spray-dried canola oil: from $2.4 \%(w / w)$ (the coat containing lentil protein isolate, maltodextrin, and sodium alginate) to $11.5 \%(w / w)$ (the coat containing lentil protein isolate, maltodextrin, sodium alginate, and lecithin). Carneiro et al. [2013] reported that the encapsulation efficiency was significantly influenced by the type of wall material used. In their experiment, PE determined for flax seed oil encapsulated by spray-drying varied from $62.3 \%$ (sample coated with whey protein concentrate and maltodextrin) to $95.7 \%(w / w)$ (sample coated with Hi-Cap waxy maize and maltodextrin). On the other hand, Umesha et al. [2013] studied the influence of oil and wall material proportion in emulsion on characteristics of garden cress seed oil encapsulation by spray-drying. They found that an increase in the oil/wall material ratio in the range from 0.1 to 0.75 decreased the PE by increasing the surface oil content. Those authors obtained a significantly higher surface oil content $(7.8-13.6 \%, w / w)$ and a lower PE $(47.5-73.3 \%, w / w)$ for an oil/wall material ratio of 0.5 , that is comparable to the present study. Also Tonon et al. [2012] showed a relationship between oil loading and encapsulation efficiency of flax seed oil. They suggested lower oil loading (10-40\%,w/w) in the encapsulation by spray-drying than in the present study. In turn, Hasani et al. [2015] confirmed the influence of different wall materials on the freeze-drying efficiency. In their study, fish oil was encapsulated with PE ranging from $70.74 \%$ for a maltodextrin, sodium caseinate, whey protein concentrate, and modified starch (Hi-Cap 100) mixture to $88.55 \%$ $(w / w)$ for a mixture without sodium caseinate. The review of different methods of encapsulation presented by Ruiz Ruiz et al. [2017] showed that the key parameter in any of these processes was the selection of wall material. They reported that protein or polysaccharides were primarily used as shell materials in the spray-drying method.

Although most studies indicate the strong impact of wall material composition and oil loading on the process efficiency and the surface oil content, the emulsification method and drying parameters will also have an effect on the encapsulation process [Aksoylu \& Günç Ergönül, 2017; Heinzelmann et al., 2000]. Nonetheless, literature data shows that
PE decreased with an increasing surface oil content for both methods of powder production [Calvo et al., 2011; Karaca et al., 2013], as was noted in the present study.

As was pointed out in the present study, the oil samples encapsulated by freeze-drying had a higher surface oil content than the encapsulated by spray-drying. This phenomenon was also noticed by others researchers [Anwar \& Kunz, 2011; Karaca et al., 2013; Quispe-Condori et al., 2011]. This is mainly due to the difference in the dehydration mechanism in these methods, which greatly affects the microstructure and integrity of the capsule wall. As a result of encapsulation by freeze-drying, the porous and irregular structure of flakes is observed (Figure 1). In particular, those particles of a larger size are easily destroyed, which can lead to powder structure opening and to oil leakage. Silva et al. [2016] explained that ice crystals are formed during the freezing stage preceding encapsulation, which contributes to the rupture of the emulsion droplets, thus releasing oil from the particle to the surface.

The results in Table 1 also show the effect of oil type on the encapsulation efficiency. In the case of encapsulation by spray-drying, the highest process efficiency was obtained for the rape seed oil, whereas the lowest was for the safflower seed oil. In turn, for freeze-drying, the safflower seed oil was slightly more effectively encapsulated than rape and flax seed oils. This property was strongly negatively correlated with the surface oil content. However, the total oil content differed only slightly among the samples (up to $4 \%$ ) and the differences noted for each drying method separately were not statistically significant $(p>0.05)$. Only sparse literature data address the encapsulation process of different oils under the same conditions. Shivakumar et al. [2012] found that safflower seed oil was effectively encapsulated by spray-drying at a higher percentage (up to $70 \%(w / w)$ total oil and 15\% $(w / w)$ free oil) compared to flax seed oil (up to $65 \%(w / w)$ of total oil and 19\% (w/w) of free oil). In turn, Calvo et al. [2012] studied the influence of olive oil quality on the spray-drying effectiveness and observed no significant differences among monovarietal and blend-type extra-virgin olive oils. Mikulcová et al. [2017] studied the effect of oil type (refined and unrefined hemp seed oils) on the distribution of particles in an emulsion and showed that both oils performed similarly under high-intensity emulsification. The differences in surface oil content and process efficiency of the oil pow- 
$1 \mathrm{a}$

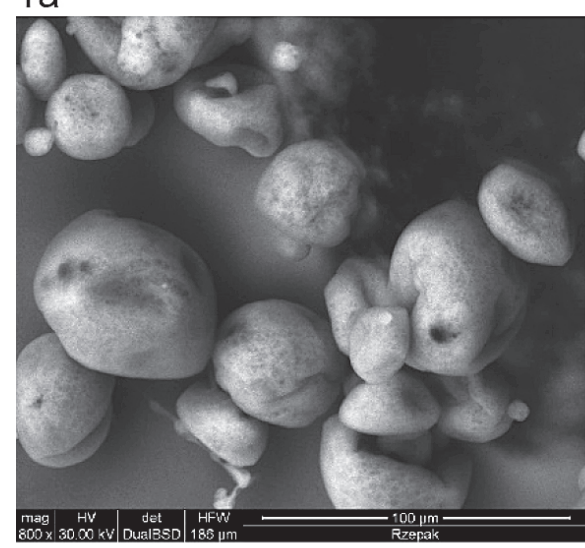

$1 \mathrm{~b}$

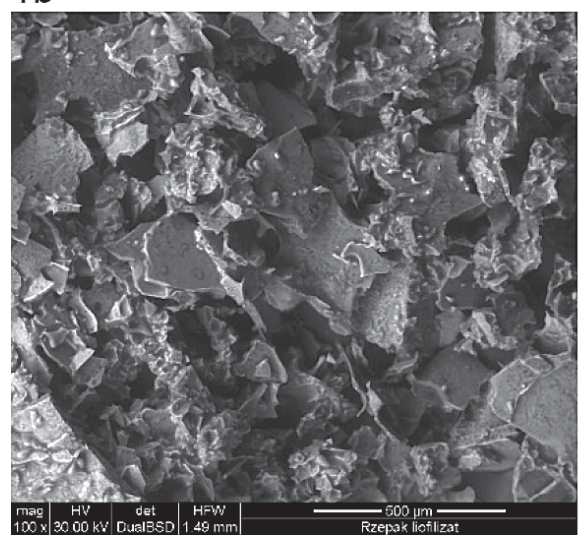

$2 a$

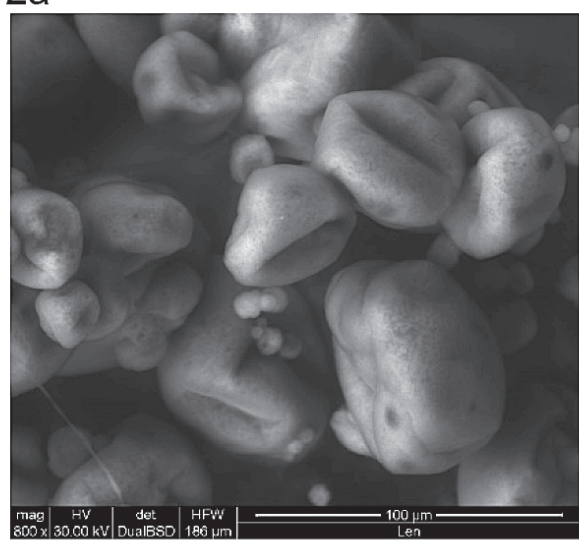

$2 b$

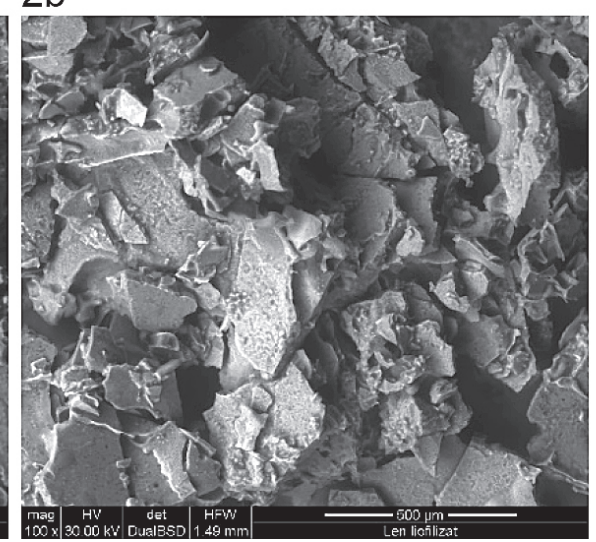

$3 a$

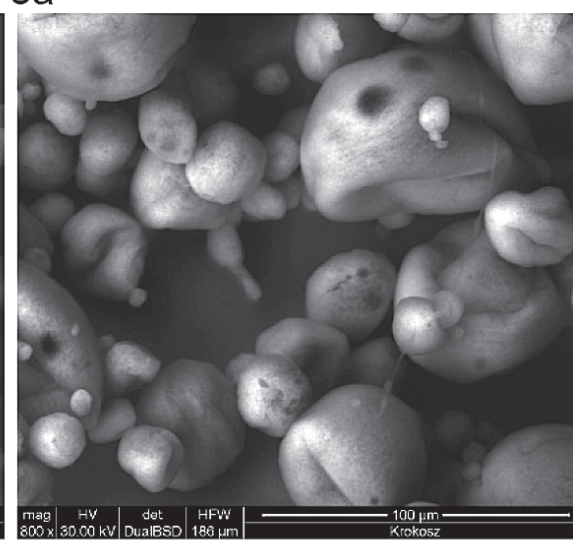

$3 b$

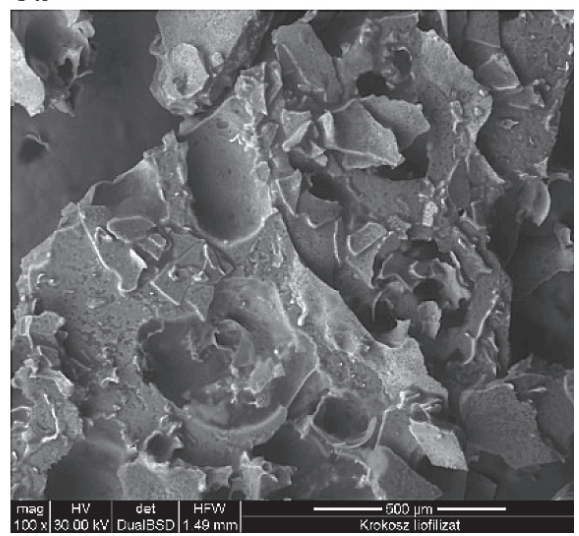

FIGURE 1. Scanning electron microscopy images of powders from cold-pressed rape (1), flax (2), and safflower (3) seed oils obtained by spry-drying (a, mag $800 \times$ ) and freeze-drying (b, mag 100×) showing differences in powder morphology.

ders obtained by spray-drying were probably due to oil composition. The oils differ significantly in their fatty acid composition and unsaponifiable compounds content (including tocopherols), which could affect the emulsion droplet size and viscosity. Lindenstruth \& Müller [2004] reported that the production process parameters (pressure and temperature) had a lesser influence on the emulsion properties than the composition of oil and surfactant phase. In their opinion, if a dispersed phase with small droplet sizes is needed, unsaturated components in the oil phase should be avoided. As shown by Tonon et al. [2012], the process efficiency decreased exponentially with droplet size and increased linearly with emulsion viscosity. This phenomenon was also observed in our study. It was noticed that the drying of the emulsion prepared with rape seed oil, which was characterized by a larger droplet size and greater viscosity $(1.28 \mathrm{mPa} \cdot \mathrm{s})$, was more effective than the drying of emulsion with flax and safflower seed oils, whose emulsion viscosities were at 1.01 and $1.03 \mathrm{mPa} \cdot \mathrm{s}$, respectively (Table 2). This difference may be related to the fatty acid composition of the oils. Yalcin et al. [2012] reported that viscosity of the various vegetable oils depended on their fatty acid composition and increased as chain length and degree of saturation of fatty acids increased. Our results are in agreement with the finding from this study. Rape seed oil had the lowest amount of polyunsaturated fatty acids (PUFA) and the highest amount of monounsaturated fatty acids (MUFA) from all analyzed oils (Table 3). Badke et al. [2019] also found a correlation between encapsulation efficiency and the chemical composition of encapsulated oil. According to their suggestion, when the core material is highly hydrophobic, it is necessary to use surfactants which will increase the affinity of the core with the shell, enhancing the encapsulation efficiency. Barbosa et al. [2005] reported that the encapsulation efficiency depended also on the emulsion stability. In their study, the lower amount of non-encapsulated material on particles surface was obtained from a more stable emulsion. However, in the present study, the results obtained for the encapsulation efficiency were not affected by the emulsion stability. All emulsions were stable over the 24-h storage at room temperature, showing no phase separation (Table 2).

TABLE 2. Characteristics of basic parameters of emulsions obtained from cold-pressed oils.

\begin{tabular}{l|c|c|c}
\hline $\begin{array}{l}\text { Type of } \\
\text { cold-pressed oil }\end{array}$ & $\begin{array}{c}\text { Stability } \\
\text { after } 24 \mathrm{~h} \\
(\%, v / v)\end{array}$ & $\begin{array}{c}\text { Viscosity } \\
(\mathrm{mPa} \times \mathrm{s}, w / w)\end{array}$ & $\begin{array}{c}\text { Droplet size } \\
\mathrm{D}[4,3] \\
(\mu \mathrm{m})\end{array}$ \\
\hline Rape seed oil & $0.00 \pm 0.01^{\mathrm{a}}$ & $1.28 \pm 0.02^{\mathrm{a}}$ & $8.19 \pm 0.34^{\mathrm{a}}$ \\
Flax seed oil & $0.00 \pm 0.00^{\mathrm{a}}$ & $1.03 \pm 0.01^{\mathrm{b}}$ & $4.58 \pm 0.49^{\mathrm{b}}$ \\
Safflower seed oil & $0.00 \pm 0.02^{\mathrm{a}}$ & $1.01 \pm 0.01^{\mathrm{b}}$ & $4.37 \pm 0.06^{\mathrm{b}}$ \\
\hline
\end{tabular}

Mean values in columns, for each type of oil separately, denoted by the same letter do not differ statistically significantly at $\mathrm{p}>0.05$ (Tukey test). 
TABLE 3. Fatty acid composition of natural and powdered cold-pressed oils expressed as area percentage of each fatty acid in total area of all fatty acids and their changes after drying process.

\begin{tabular}{|c|c|c|c|c|c|c|c|c|c|c|}
\hline \multirow{2}{*}{$\begin{array}{l}\text { Type of } \\
\text { cold-pressed } \\
\text { oil }\end{array}$} & \multirow{2}{*}{$\begin{array}{c}\text { Emulsion } \\
\text { drying } \\
\text { method }\end{array}$} & \multicolumn{9}{|c|}{ Fatty acids (area \%) } \\
\hline & & $\begin{array}{c}\text { Myristic } \\
\text { C14:0 }\end{array}$ & $\begin{array}{c}\text { Palmitic } \\
\text { C16:0 }\end{array}$ & $\begin{array}{l}\text { Stearic } \\
\text { C18:0 }\end{array}$ & $\begin{array}{c}\text { Oleic } \\
\text { C18:1n-9 } \\
\end{array}$ & $\begin{array}{c}\text { Linoleic } \\
\text { C18:2 n-6 } \\
\end{array}$ & $\begin{array}{l}\text { Linolenic } \\
\text { C18:3n-3 } \\
\end{array}$ & $\Sigma \mathrm{SFA}$ & $\Sigma$ MUFA & $\Sigma$ PUFA \\
\hline \multirow{5}{*}{ Rape seed oil } & - & n.d. & $4.23 \pm 0.13^{b}$ & $1.26 \pm 0.26^{\mathrm{b}}$ & $67.23 \pm 1.56^{\mathrm{a}}$ & $18.61 \pm 0.08^{\mathrm{a}}$ & $8.67 \pm 1.24^{\mathrm{a}}$ & $5.49 \pm 0.40^{\mathrm{b}}$ & $67.23 \pm 1.56^{\mathrm{a}}$ & $27.28 \pm 1.16^{\mathrm{a}}$ \\
\hline & SD & n.d. & $5.09 \pm 0.06^{\mathrm{a}}$ & $1.92 \pm 0.04^{\mathrm{a}}$ & $68.28 \pm 0.58^{\mathrm{a}}$ & $17.31 \pm 0.43^{\mathrm{b}}$ & $7.41 \pm 0.25^{b}$ & $7.01 \pm 0.10^{\mathrm{a}}$ & $68.28 \pm 0.58^{\mathrm{a}}$ & $24.71 \pm 0.68^{\mathrm{b}}$ \\
\hline & & n.d. ${ }^{*}$ & +20.3 & +52.4 & +1.6 & -7.0 & -14.5 & +27.7 & +1.6 & -9.4 \\
\hline & FD & n.d. & $4.80 \pm 0.18^{\mathrm{a}}$ & $1.87 \pm 0.01^{\mathrm{a}}$ & $67.73 \pm 0.25^{\mathrm{a}}$ & $17.74 \pm 0.44^{b}$ & $7.86 \pm 0.01^{\mathrm{ab}}$ & $6.67 \pm 0.19^{\mathrm{a}}$ & $67.73 \pm 0.25^{\mathrm{a}}$ & $25.61 \pm 0.44^{b}$ \\
\hline & & n.d. & +13.5 & +48.4 & +0.7 & -4.7 & -9.3 & +21.5 & +0.7 & -6.1 \\
\hline \multirow{5}{*}{ Flax seed oil } & - & n.d. & $5.55 \pm 0.35^{\mathrm{c}}$ & $3.26 \pm 0.04^{c}$ & $16.53 \pm 0.06^{\mathrm{a}}$ & $11.26 \pm 0.13^{b}$ & $63.41 \pm 0.33^{\mathrm{a}}$ & $8.81 \pm 0.39^{\mathrm{b}}$ & $16.53 \pm 0.06^{\mathrm{a}}$ & $74.67 \pm 0.45^{\mathrm{a}}$ \\
\hline & SD & n.d. & $7.49 \pm 0.05^{\mathrm{a}}$ & $4.19 \pm 0.03^{\mathrm{a}}$ & $17.63 \pm 0.22^{\mathrm{a}}$ & $13.35 \pm 0.48^{\mathrm{a}}$ & $57.35 \pm 0.18^{c}$ & $11.68 \pm 0.08^{\mathrm{a}}$ & $17.63 \pm 0.22^{\mathrm{a}}$ & $70.70 \pm 0.30^{c}$ \\
\hline & & n.d. & +34.9 & +28.5 & +6.6 & +18.7 & -9.6 & +32.3 & +6.6 & -5.3 \\
\hline & FD & n.d. & $6.46 \pm 0.28^{b}$ & $3.72 \pm 0.37^{\mathrm{b}}$ & $17.17 \pm 0.16^{\mathrm{a}}$ & $11.34 \pm 0.01^{\mathrm{b}}$ & $61.33 \pm 0.82^{b}$ & $10.17 \pm 0.65^{\mathrm{a}}$ & $17.17 \pm 0.16^{\mathrm{a}}$ & $72.67 \pm 0.81^{b}$ \\
\hline & & n.d. & +16.4 & +14.1 & +3.9 & +0.7 & -3.3 & +15.4 & +3.9 & -2.7 \\
\hline \multirow{5}{*}{$\begin{array}{l}\text { Safflower } \\
\text { seed oil }\end{array}$} & - & $0.34 \pm 0.05^{\mathrm{ab}}$ & $6.80 \pm 0.07^{c}$ & $2.50 \pm 0.27^{\mathrm{a}}$ & $11.99 \pm 0.17^{b}$ & $77.69 \pm 0.47^{\mathrm{a}}$ & $0.69 \pm 0.01^{\mathrm{a}}$ & $9.64 \pm 0.29^{a}$ & $11.99 \pm 0.17^{\mathrm{b}}$ & $78.38 \pm 0.46^{\mathrm{a}}$ \\
\hline & SD & $0.46 \pm 0.12^{\mathrm{a}}$ & $7.80 \pm 0.01^{\mathrm{a}}$ & $2.56 \pm 0.08^{\mathrm{a}}$ & $18.73 \pm 0.90^{\mathrm{a}}$ & $69.13 \pm 1.14^{c}$ & $1.34 \pm 0.28^{\mathrm{a}}$ & $10.82 \pm 0.02^{\mathrm{a}}$ & $18.73 \pm 0.45^{\mathrm{a}}$ & $70.46 \pm 0.43^{c}$ \\
\hline & & +35.3 & +14.7 & +2.4 & +56.2 & -11.0 & +94.2 & +12.2 & +56.2 & -10.1 \\
\hline & FD & $0.29 \pm 0.06^{b}$ & $7.11 \pm 0.06^{\mathrm{b}}$ & $2.44 \pm 0.08^{\mathrm{a}}$ & $18.34 \pm 0.23^{\mathrm{a}}$ & $71.03 \pm 0.13^{b}$ & $0.81 \pm 0.05^{\mathrm{a}}$ & $9.83 \pm 0.05^{\mathrm{a}}$ & $18.34 \pm 0.23^{\mathrm{a}}$ & $71.84 \pm 0.18^{b}$ \\
\hline & & -14.7 & +4.6 & -2.4 & +53.0 & -8.6 & +17.4 & +2.0 & +53.0 & -8.3 \\
\hline
\end{tabular}

Mean values in columns, for each type of oil separately, denoted by the same letter do not differ statistically significantly at $\mathrm{p}>0.05$ (Tukey test).

SFA - saturated fatty acids, MUFA - monounsaturated fatty acids, PUFA - polyunsaturated fatty acids, SD - spray-drying, FD - freeze-drying, n.d. - not detected.

* Lines in italics present percentage changes in concentrations of individual compounds and their groups in the powdered oils relative to the natural cold-pressed oils.

Fatty acid composition in cold-pressed oils and oil powders

The fatty acid composition of the examined cold-pressed oils is shown in Table 3. The major fatty acid in the natural rape seed oil was monounsaturated oleic acid (C18:1 n-9) with the percentage share of 67.23 area $\%$. The contents of C18:2 n-6 and C18:3n-3 acids in this oil were 18.61 and 8.67 area $\%$, respectively. The content of saturated fatty acids (SFA) was low, and accounted for 5.49 area \%. The results obtained for natural cold-pressed oil correspond to the results obtained by other researchers [Lewinska et al., 2015; Roszkowska et al., 2015]. Flax and safflower seed oils had a high level of polyunsaturated fatty acids, which accounted for 78 area \% of all fatty acids. In turn, C18:3n-3 acid prevailed in the flax seed oil, and its share was 63.41 area $\%$. The second polyunsaturated fatty acid, C18:2 n-6, in this oil accounted for 11.26 area $\%$. In turn, saturated fatty acids (SFA) and MUFA reached, on average, 10 area \% and 17 area $\%$ in this oil. A similar composition of fatty acids in cold-pressed flax seed oil was reported in other studies [Khattab \& Zeitoun, 2013; Tańska et al., 2016]. C18:2 n-6 was the major acid in safflower seed oils (77.69 area \%), while the share of $\mathrm{C} 18: 3 n-3$ did not exceed 1.5 area $\%$. A similar content of linoleic acid (76.58\%) in safflower seed oil was reported by Dorni et al. [2018].

In rape seed oil powders obtained both as a result of encapsulation by spray- and freeze-drying, a reduction was observed (by 4.7-14.5\%) in the percentage share of polyunsaturated fatty acids: linoleic (C18:2 n- 6$)$ and $\alpha$-linolenic (C18:3 n-3). However, considerable changes were observed in saturated fatty acids: palmitic (C16:0) and stearic (C18:0), whose shares increased to $13.5-20.3 \%$ and $48.4-52.4 \%$, respectively. Changes in percentage shares of PUFA only slightly affected the ratio of $n-6$ to $n-3$ fatty acids. In the natural rape seed oil, this ratio was at 2.01:1, while in the encapsulated rape seed oils it reached 2.03:1. In the encapsulated flax seed oil, C18:3n-3 acid share was reduced by $9.6 \%$ (for spray-drying method) and by $3.3 \%$ (for freeze-drying method). The content of C18:2 n-6 was the highest in the oil encapsulated by spray-drying. Saturated fatty acids accounted for, on average, $10 \%$ and $17 \%$ in flax seed oils. The contents of SFA and MUFA increased after the encapsulation process, but statistically significant changes $(\mathrm{p} \leq 0.05)$ were found only for SFA. Quispe-Condori et al. [2011] also encapsulated flax seed oil, using the spray- and freeze-drying methods. Although they observed no change in the $\alpha$-linolenic acid content after spray-drying process, the content of this acid decreased during freeze-drying. During encapsulation of flax seed oil by spray-drying, Barroso et al. [2014] also observed an increase in the content of SFAs and a decrease in linolenic acid content. The drying of an emulsion with safflower seed oil resulted in greater losses of PUFAs in comparison to rape and flax seed oils; these losses reached $10.1 \%$ with the spray- 
-drying and $8.3 \%$ with the freeze-drying method. Additionally, noticeably greater changes were observed in the content of MUFAs in comparison to other oils. The share of those acids increased as a result of drying process by more than $50 \%$, while in rape and flax seed oils their increase did not exceed $7 \%$. The changes in the percentage share of fatty acids probably resulted from the drying temperature applied. However, it is not confirmed by the research conducted by Kwon et al. [2004] who did not observe any changes in the fatty acid composition of oils obtained as a result of safflower seed roasting at $140-180^{\circ} \mathrm{C}$.

When comparing the results for encapsulated oils with the results for crude oils, a decrease in the percentage of the PUFAs was observed. The highest degradation of PUFAs was observed in spray-dried safflower seed oil powder $(10.11 \%)$, while the lowest degradation was in freeze-dried flax seed oil powder (2.68\%). Hue \& Nyam [2018], who studied the encapsulation of kenaf seed oil by freeze-drying, noted a lower decrease of the PUFA share, which was $2.29 \%$. Calvo et al. [2010] also observed only small changes in the fatty acid composition of extra-virgin olive oil during freeze-drying; including a decrease in the PUFA share (up to $4.3 \%$ ) and an increase in the MUFA share (up to $1.3 \%$ ). In contrast, the spray-drying of an emulsion with extra-virgin olive oils performed by Calvo et al. [2012] significantly modified the fatty acid composition. In that study, the PUFA share was reduced by 5.3-69.6\% depending on the type of olive oil. Additionally, generally greater PUFA losses were found for oil samples along with higher percentage shares. This contradicts the results of our study, in which twofold greater changes were recorded for the encapsulated rape seed oils than for the encapsulated flax seed oils that were clearly richer in PUFAs. Wang et al. [2018] also reported no significant effect of the spray-drying method on the composition of fatty acids in peony seed oil characterized by a high PUFA share (39.24\% (w/w) of C18:3n-3 and 26.96\% (w/w) of C18:3n-6). Rubilar et al. [2012] also showed a reduction in MUFAs in flax seed oil as a result of the spray-drying process. In their study, the content of linolenic acid decreased slightly during the process, but the contents of oleic and linoleic acids decreased by almost 50\%. In the work of Ogrodowska et al. [2017], regardless of the draying method and processes temperature used, the PUFA losses in pumpkin seed oil ranged from 6.00 to $7.15 \%$. The differences in the PUFA losses observed between the studied oils are likely to result from not only the content of prooxidants and antioxidants but also the droplet size of emulsions prepared with their use. This is consistent with our results where the emulsion containing safflower seed oil had particles with the smallest diameter $\mathrm{D}[4,3]$ (Table 2), and after drying the greatest degradation of PUFAs was observed.

Hogan et al. [2003] showed an antioxidative effect of $100 \mathrm{mg} / \mathrm{kg} \alpha$-tocopherol addition on fish oil subjected to the spray-drying, while $500 \mathrm{mg} / \mathrm{kg}$ of $\alpha$-tocopherol contributed to a significant increase in the peroxide and anisidine values in encapsulated oil compared to the control sample. In turn, Coupland et al. [1996] demonstrated that the rate of lipid oxidation increased as the mean diameter of the droplet decreased because the droplet surface was increasing, which increased the contact between the interface, oxygen and radicals in the solution and thus enabled the unsaturated lipid located on the interface to oxidize easily. Furthermore, they also suggested that the ratio of oxidizable-to-nonoxidizable compounds in emulsion droplets affected the rate at which the lipid oxidation proceeds.

A greater influence of the encapsulation by spray-drying on fatty acid composition compared to freeze-drying observed for the studied oils could be explained by the oil oxidation rate during the processes. The spray-drying requires using high temperatures, which can affect the labile components of oils. Considering even such factors as the cooling effect of water evaporation from the dried emulsion or the short time of its residence in the drying chamber, hydroperoxide formation is high as a result of accelerated oxidation [Aghbashlo et al., 2013]. Anwar \& Kunz [2011] also confirmed that even though spray-drying only needed a few seconds to produce a desirable size of granules, it had a high chance of lipid degradation by oxidation due to the high drying temperature in the process. Timilsena et al. [2017] reported that complex coacervation-based microencapsulation better protected PUFAs-rich oils than a simple spray drying. They explained that the higher encapsulation efficiency in the complex coacervation-based microencapsulation resulted from the better surface-active nature of the complex coacervates.

\section{Content of sterols in cold-pressed oils and oil powders}

The sterol content in the examined cold-pressed oils is presented in Table 4. All examined oils contained $\Delta 5$-avenasterol, campesterol, $\beta$-sitosterol, and $\Delta 7$-avenasterol. Additionally, brassicasterol (37.32 mg/100 g of oil) was present in rape seed oil and $\Delta 7$-sitosterol in flax and safflower seed oils (115.34 and $0.79 \mathrm{mg} / 100 \mathrm{~g}$ of oil, respectively).

The total sterols in rape seed oil amounted to $505.46 \mathrm{mg} / 100 \mathrm{~g}$ of oil. A higher content of sterols, ranging from 596.4 to $772.5 \mathrm{mg} / 100 \mathrm{~g}$ of oil, was presented in work by Krajlić et al. [2013], who examined rape seed oil obtained from seeds cultivated in Croatia. In turn, Roszkowska et al. [2015] found 338.6-411.8 mg/100 g sterols in commercial cold-pressed rape seed oils available in Poland. Both the spray- and the freeze-drying processes resulted in the similar degradation of sterols, by $61.34 \%$ and $61.93 \%$, respectively (Table 4).

Flax seed oil had the highest content of total sterols (477.82 mg/100 g of oil) compared to the other oils tested. A similar content of total sterols in flax seed oil was determined by Zhang et al. [2018] and Tańska et al. [2016]. The results obtained (Table 4) demonstrated a higher degradation of total sterols in freeze-dried flax seed oil (by 65.82\%) than in the spray-dried oil (by 59.91\%).

The lowest total sterol level $(303.97 \mathrm{mg} / 100 \mathrm{~g}$ of oil) in comparison to the other oils under analysis was determined in safflower seed oil. This result agrees with the findings reported by Nogala-Kalucka et al. [2010]. The process of safflower seed oil powder production contributed to significant sterol losses, amounting to $59.01 \%$ (spray-drying method) and $60.85 \%$ (freeze-drying method).

$\beta$-Sitosterol was the major sterol in the examined cold-pressed oils, which has been confirmed in other studies 
TABLE 4. Content of sterols in natural and powdered cold-pressed oils and their changes after drying process.

\begin{tabular}{|c|c|c|c|c|c|c|c|c|c|}
\hline \multirow{2}{*}{$\begin{array}{l}\text { Type of } \\
\text { cold-pressed } \\
\text { oil }\end{array}$} & \multirow{2}{*}{$\begin{array}{c}\text { Emulsion } \\
\text { drying } \\
\text { method }\end{array}$} & \multicolumn{7}{|c|}{ Sterols (mg/100 $\mathrm{g}$ of oil) } & \multirow{2}{*}{$\begin{array}{c}\text { Total } \\
\text { (mg/100 g } \\
\text { of oil) }\end{array}$} \\
\hline & & Brassicasterol & $\Delta 5$-Avenasterol & Campesterol & $\beta$-Sitosterol & $\Delta 7$-Avenasterol & $\Delta 7$-Sitosterol & Others & \\
\hline \multirow{5}{*}{ Rape seed oil } & - & $37.32 \pm 4.60^{\mathrm{a}}$ & $18.98 \pm 2.30^{\mathrm{a}}$ & $177.88 \pm 4.92^{\mathrm{a}}$ & $237.02 \pm 4.29^{\mathrm{a}}$ & $26.65 \pm 2.33^{\mathrm{a}}$ & n.d. & $7.60 \pm 1.57^{\mathrm{a}}$ & $505.46 \pm 8.26^{\mathrm{a}}$ \\
\hline & SD & $18.20 \pm 0.54^{b}$ & $6.06 \pm 1.10^{\mathrm{b}}$ & $71.47 \pm 3.40^{\mathrm{b}}$ & $89.87 \pm 3.04^{b}$ & $5.91 \pm 0.41^{\mathrm{c}}$ & n.d. & $2.68 \pm 0.47^{c}$ & $195.43 \pm 7.49^{\mathrm{b}}$ \\
\hline & & $-51.23^{*}$ & -68.04 & -59.82 & -62.08 & -77.80 & - & -64.66 & -61.34 \\
\hline & FD & $15.49 \pm 0.80^{\mathrm{c}}$ & $7.02 \pm 0.31^{\mathrm{b}}$ & $67.40 \pm 3.06^{\mathrm{c}}$ & $88.92 \pm 3.70^{\mathrm{b}}$ & $10.50 \pm 0.54^{\mathrm{b}}$ & n.d. & $3.08 \pm 0.27^{\mathrm{b}}$ & $192.41 \pm 2.75^{b}$ \\
\hline & & -58.50 & -63.02 & -62.11 & -62.48 & -60.58 & - & -59.49 & -61.93 \\
\hline \multirow{5}{*}{ Flax seed oil } & - & n.d. & $27.48 \pm 0.56^{\mathrm{a}}$ & $98.91 \pm 2.09^{\mathrm{a}}$ & $159.41 \pm 1.44^{a}$ & $64.23 \pm 1.78^{\mathrm{a}}$ & $115.34 \pm 0.35^{\mathrm{a}}$ & $12.44 \pm 0.61^{\mathrm{a}}$ & $477.82 \pm 4.14^{\mathrm{a}}$ \\
\hline & SD & n.d. & $2.46 \pm 0.09^{b}$ & $37.59 \pm 2.56^{\mathrm{b}}$ & $80.54 \pm 0.10^{\mathrm{b}}$ & $14.48 \pm 0.51^{\mathrm{b}}$ & $44.22 \pm 2.15^{\mathrm{c}}$ & $12.24 \pm 0.85^{\mathrm{a}}$ & $191.53 \pm 3.40^{\mathrm{b}}$ \\
\hline & & - & -91.05 & -62.00 & -49.48 & -77.45 & -61.66 & -1.68 & -59.91 \\
\hline & FD & n.d. & $2.81 \pm 0.41^{\mathrm{b}}$ & $34.71 \pm 0.43^{\mathrm{c}}$ & $71.97 \pm 4.56^{\mathrm{c}}$ & $1.18 \pm 0.08^{c}$ & $49.05 \pm 4.17^{\mathrm{b}}$ & $3.60 \pm 0.40^{\mathrm{b}}$ & $163.33 \pm 2.68^{c}$ \\
\hline & & - & -89.78 & -64.91 & -54.85 & -98.16 & -57.47 & -71.11 & -65.82 \\
\hline \multirow{5}{*}{$\begin{array}{l}\text { Safflower } \\
\text { seed oil }\end{array}$} & - & n.d. & $10.35 \pm 0.59^{\mathrm{a}}$ & $98.47 \pm 2.79^{\mathrm{a}}$ & $130.63 \pm 4.10^{\mathrm{a}}$ & $15.54 \pm 0.64^{\mathrm{a}}$ & $0.79 \pm 0.01^{\mathrm{a}}$ & $3.73 \pm 0.05^{\mathrm{a}}$ & $303.97 \pm 5.60^{\mathrm{a}}$ \\
\hline & SD & - & $1.07 \pm 0.13^{\mathrm{b}}$ & $25.01 \pm 0.16^{\mathrm{b}}$ & $74.60 \pm 1.20^{\mathrm{b}}$ & $9.01 \pm 0.04^{\mathrm{b}}$ & $0.22 \pm 0.02^{\mathrm{b}}$ & $3.12 \pm 0.02^{\mathrm{b}}$ & $122.86 \pm 5.99^{b}$ \\
\hline & & - & -89.59 & -74.60 & -42.89 & -41.98 & -72.98 & -16.55 & -59.01 \\
\hline & $\mathrm{FD}$ & n.d. & $1.23 \pm 0.16^{\mathrm{b}}$ & $24.71 \pm 1.509^{b}$ & $71.35 \pm 0.83^{\mathrm{c}}$ & $6.96 \pm 1.05^{\mathrm{c}}$ & $0.20 \pm 0.01^{\mathrm{b}}$ & $3.50 \pm 0.28^{\mathrm{a}}$ & $112.62 \pm 2.87^{b}$ \\
\hline & & - & -88.13 & -74.90 & -45.38 & -55.16 & -74.42 & -6.23 & -60.85 \\
\hline
\end{tabular}

Mean values in columns, for each type of oil separately, denoted by the same letter do not differ statistically significantly at p $>0.05$ (Tukey test). SD spray-drying, FD - freeze-drying, n.d. - not detected.

* Lines in italics present percentage changes in contents of individual compounds and their total content in the powdered oils relative to the natural cold-pressed oils.

[Czaplicki et al., 2016; Nogala-Kalucka et al., 2010; Rudzińska et al., 2009]. The highest content of $\beta$-sitosterol was determined in rape seed oil $(237.02 \mathrm{mg} / 100 \mathrm{~g}$ of oil), and the lowest one in oil obtained from safflower seed oil $(130.63 \mathrm{mg} / 100 \mathrm{~g}$ of oil). Encapsulated oil production resulted in the significant degradation of $\beta$-sitosterol, although the range of these changes did not depend on the method applied, but on oil type. The greatest losses of this component (about 63\%) were found for rape seed oil, while the smallest ones in the safflower seed oil (on average 44.5\%). The flax and safflower seed oils were also characterized by the highest degradation of $\Delta 5$-avenasterol (by $88.13-91.05 \%$ ). Additionally, the greatest degradation of brassicasterol was observed in the safflower seed oil, which was $88.94 \%$ (spray-dried sample) and $89.51 \%$ (freeze-dried sample). Hue \& Nyam [2018] reported that the unsaturated bond in chemical structures was the major difference among various sterols and the main reason for the degradation of the sterols. $\beta$-Sitosterol has one double bond [Hue \& Nyam, 2018], while brassicasterol and avenasterol have two double bonds in their molecules; and this may affect the rate of their degradation [Gawrysiak-Witulska et al., 2015]. Our results generally confirmed this phenomenon, with the exception of brassicasterol in the rape seed oils and $\Delta 7$ avenasterol in the spray-dried safflower seed oil.

The available literature does not include many studies describing the effect of the powder production process on degradation of biologically active substances, including sterols. The studies on those compounds have been conducted mainly in the context of their changes under the effect of applied technological operations or, generally, of heating. Sterols are among the compounds which are subject to degradation as a result of heat factors, which results in a variety of oxidative derivatives (oxysterols) formed [Rudzińska et al., 2009]. Hernández Sánchez et al. [2016] found that during spray-drying, emulsion drops were in contact with hot air. During the process, at the beginning water is removed, drying liquid drops remain at the air wet bulb temperature $\left(e . g\right.$. about $\left.40^{\circ} \mathrm{C}\right)$ and their temperature may then start increasing at the end of drying when the air current has reached a temperature close to its outlet temperature (e.g. $\left.94-110^{\circ} \mathrm{C}\right)$. Dry particles may therefore be exposed, for a very short time, to high temperatures, which can create favorable conditions for the formation of oxidation products. On the other hand, Soupas et al. [2006] reported that more sterol oxides were generated during storage of milk powder than during spray-drying.

Considering only the total content of sterols in the analyzed samples, it should be noted that the process of encapsulated oil production by freeze-drying contributed to their greater degradation. An opposite relationship was found in the experiment of Kim et al. [2014] who determined the content of bioactive compounds in rice bran subjected to different heat treatments. They observed that the sterol content in a freeze-dried and then dry-heated sample was slightly lower than in the control sample. Furthermore, the sterol content linearly decreased as the heating temperature or time increased. Kwon et al. [2004], who studied the effect of heat 
TABLE 5. Content of tocopherols in natural and powdered cold-pressed oils and their changes after drying process.

\begin{tabular}{|c|c|c|c|c|c|}
\hline \multirow{2}{*}{ Type of cold-pressed oil } & \multirow{2}{*}{$\begin{array}{c}\text { Emulsion } \\
\text { drying method }\end{array}$} & \multicolumn{3}{|c|}{ Tocopherols (mg/100 g of oil) } & \multirow{2}{*}{ Total (mg/100 g of oil } \\
\hline & & $\alpha$ & $\beta+\gamma$ & $\delta$ & \\
\hline \multirow{5}{*}{ Rape seed oil } & - & $31.60 \pm 0.18^{\mathrm{a}}$ & $33.56 \pm 0.95^{\mathrm{a}}$ & $0.07 \pm 0.01^{\mathrm{a}}$ & $65.16 \pm 1.13^{\mathrm{a}}$ \\
\hline & SD & $26.29 \pm 1.73^{\mathrm{b}}$ & $28.67 \pm 2.23^{b}$ & n.d. & $54.95 \pm 3.97^{\mathrm{b}}$ \\
\hline & & $-16.8 *$ & -14.6 & -100.0 & -15.7 \\
\hline & FD & $21.80 \pm 2.22^{\mathrm{c}}$ & $27.71 \pm 2.64^{\mathrm{b}}$ & $0.05 \pm 0.01^{\mathrm{a}}$ & $49.51 \pm 0.42^{\mathrm{c}}$ \\
\hline & & -31.0 & -17.4 & -26.5 & -24.0 \\
\hline \multirow{5}{*}{ Flax seed oil } & - & $5.43 \pm 0.50^{\mathrm{a}}$ & $41.83 \pm 1.06^{\mathrm{a}}$ & $0.09 \pm 0.01^{\mathrm{a}}$ & $47.26 \pm 0.57^{\mathrm{a}}$ \\
\hline & SD & $5.40 \pm 0.51^{\mathrm{a}}$ & $33.91 \pm 1.29^{b}$ & n.d. & $39.31 \pm 0.78^{b}$ \\
\hline & & -0.6 & -18.9 & -100.0 & -16.8 \\
\hline & FD & $3.34 \pm 0.34^{\mathrm{b}}$ & $41.73 \pm 0.02^{\mathrm{a}}$ & $0.04 \pm 0.01^{\mathrm{a}}$ & $45.07 \pm 0.36^{\mathrm{a}}$ \\
\hline & & -38.5 & -0.2 & -49.4 & -4.6 \\
\hline \multirow{5}{*}{ Safflower seed oil } & - & $54.58 \pm 2.99^{\mathrm{a}}$ & $5.52 \pm 0.08^{\mathrm{a}}$ & n.d. & $60.11 \pm 3.06^{\mathrm{a}}$ \\
\hline & $\mathrm{SD}$ & $24.71 \pm 4.02^{\mathrm{b}}$ & $5.01 \pm 0.10^{\mathrm{a}}$ & n.d. & $29.72 \pm 4.12^{\mathrm{b}}$ \\
\hline & & -54.7 & -9.3 & n.d. & -50.5 \\
\hline & FD & $54.28 \pm 0.72^{\mathrm{a}}$ & $5.03 \pm 0.02^{\mathrm{a}}$ & n.d. & $59.31 \pm 0.74^{\mathrm{a}}$ \\
\hline & & -0.9 & -8.9 & n.d. & -1.3 \\
\hline
\end{tabular}

Mean values in columns, for each type of oil separately, denoted by the same letter do not differ statistically significantly at p $>0.05$ (Tukey test). SD spray-drying, FD - freeze-drying, n.d. - not detected. * Lines in italics present percentage changes in contents of individual compounds and their total content in the powdered oils relative to the natural cold-pressed oils.

pre-treatment on the functional constituents of rice germ, reported that free sterols were degraded more easily when a high temperature or vacuum was applied because of their low boiling points. However, Hue \& Nyam [2018] observed that loss of total sterols in kenaf seed oil was $59.76 \%$ during storage, while $32.86 \%$ during freeze-drying.

\section{Content of tocopherols in cold-pressed oils and powders obtained from them}

The tocopherol content in the examined cold-pressed oils is presented in Table 5. Tocopherols are the main antioxidants of rape seed oil. The analyzed rape seed oil samples contained tocopherols at the levels of 49.51-65.16 mg/100 g of oil. The oils had high amounts of $\alpha$ - and $\beta+\gamma$-tocopherols, whereas $\delta$-tocopherol content was low. In natural rape seed oil, $\alpha$-tocopherol was present at the level of $31.60 \mathrm{mg} / 100 \mathrm{~g}$ of oil, $\beta+\gamma$-tocopherol at $33.56 \mathrm{mg} / 100 \mathrm{~g}$ of oil, and $\delta$-tocopherol at $0.07 \mathrm{mg} / 100 \mathrm{~g}$ of oil. These results concur with earlier reported findings, but most of the authors have reported that rape seed oil had high contents of $\alpha$ - and $\gamma$-tocopherols, not $\alpha$ and $\beta+\gamma$-tocopherols [Azadmard-Damirchi et al., 2010; Ghazani et al., 2014]. Rape seed oil powder production resulted in the greatest changes in the $\delta$-tocopherol content, which was subject to complete degradation as a result of spray-drying. On the other hand, after encapsulation by freeze-drying, its content was reduced by $26.5 \%$. However, freeze-drying proved to be a less favorable method for rape seed oil powder production in the case of $\alpha$-tocopherol. Its content in the freeze-dried oil was lower by $31.0 \%$, while in the spray-dried oil its decreased by $16.8 \%$. However, in both encapsulated samples, the content of $\beta+\gamma$-tocopherol was at a similar level (approx. $28 \mathrm{mg} / 100 \mathrm{~g}$ of oil).

The content of total tocopherols in the natural flax seed oil was determined at $47.26 \mathrm{mg} / 100 \mathrm{~g}$ of oil, with prevailing $\beta+\gamma$-tocopherol, accounting for $88.5 \%$. This oil contained also $\alpha$-tocopherol $(5.43 \mathrm{mg} / 100 \mathrm{~g}$ of oil) and $\delta$-tocopherol $(0.09 \mathrm{mg} / 100 \mathrm{~g}$ of oil). Similar contents of tocopherols were presented by Tańska et al. [2016], who characterized six samples of cold-pressed flax seed oil. A higher content of total tocopherols in flax seed oil, reaching $79.4 \mathrm{mg} / 100$ of oil, was obtained by Bozan \& Temelli [2008].

As a result of flax seed oil spray-drying, $\beta+\gamma$-tocopherol decreased by $18.93 \%$. However, the freeze-drying process did not affect the degradation of those flax seed oil homologues. An opposite dependency was found for $\alpha$-tocopherol, the degradation of which (by 38.5\%) occurred only after freeze-drying.

The content of tocopherols in natural safflower seed oil was comparable to that found in the rape seed oil and amounted to $60.11 \mathrm{mg} / 100 \mathrm{~g}$ of oil. However, the tocopherol profile of this oil was different, with $\alpha$-tocopherol found a major homologue, with the content reaching $54.58 \mathrm{mg} / 100 \mathrm{~g}$ of oil, i.e. ca. $90 \%$ of total tocopherols occurring in this oil. Safflower seed oil also contained $\beta$ - and $\gamma$-tocopherols, the sum of which was $5.52 \mathrm{mg} / 100 \mathrm{~g}$ of oil. A similar tocopherol content was reported by Ben Moumen et al. [2015] who characterized the lipid fractions of safflower seeds cultivated in Morocco, Spain and India. As a result of spray-drying, the content 
of $\alpha$ - and $\beta+\gamma$-tocopherols in safflower seed oil was reduced by $54.7 \%$ and $9.3 \%$, respectively (Table 5). Freeze-drying affected the content of $\beta+\gamma$-tocopherol to a degree comparable to spray-drying, but it did not affect the content of $\alpha$-tocopherol.

The encapsulation of flax and safflower seed oils by spraydrying had a greater impact on the degradation of total tocopherol content compared to the freeze-drying. Furthermore, the highest decrease in the sum of tocopherols was observed in encapsulated safflower seed oil (50.5\%). However, an opposite relationship was found in the case of rape seed oil. Gawrysiak-Witulska et al. [2015] studied the effect of drying temperature on changes in individual homologues of tocopherols in the oil from yellow-seeded rape and found that during drying at $40^{\circ} \mathrm{C}$ and $60^{\circ} \mathrm{C}$, losses of $\alpha$-, $\beta$ - and $\gamma$-tocopherols did not exceed $2 \%$, while $\delta$-tocopherol losses reached $6 \%$. Increasing air temperature to $100^{\circ} \mathrm{C}$ and $120^{\circ} \mathrm{C}$ caused similar losses $(23 \%)$ in the main tocopherol homologues in rape seed ( $\alpha$-and $\gamma$-tocopherols). Also Hernández Sánchez et al. [2016] found only $10 \%$ degradation of $\alpha$-tocopherol added to the oil before spray-drying process. A slight effect of the freeze-drying process on the tocopherol content in encapsulated oils was confirmed for walnut and kenaf seed oils [Calvo et al., 2011; Hue \& Nyam, 2018]. The powders they obtained had similar contents of tocopherols compared to the raw oils. In contrast, Calvo et al. [2010] observed that the content of tocopherols slightly increased in encapsulated olive oil produced by freeze-drying. A similar trend was observed for a freeze-dried rice sample in an experiment performed by Kim et al. [2014]. The authors suggested that a significant amount of tocopherols was lost, being bound to proteins or phospholipids, and that applying thermal energy could break the linkages.

\section{CONCLUSIONS}

Based on the research conducted, it was shown that the encapsulation efficiency and surface oil content depend not only on the encapsulation method but also on oil composition. The composition of oil, especially fatty acid composition, has a significant influence on the emulsion properties. In case of the spray-drying method, the use of rape seed oil allowed obtaining a higher encapsulation efficiency and lower surface oil content than the use of flax and safflower seed oils. For PUFAs, only a slight effect of the applied encapsulation method on their degradation was observed and it depended on oil type. In turn, sterol degradation did not depend on the drying method applied. In total, the losses of those bioactive substances in all types of oils were high and reached 60-66\%. In most cases, the native tocopherols of the studied oils were degraded to a significantly lesser extent than sterols (up to 24\%). The only exception was safflower seed oil encapsulated by spray-drying, which contained $50 \%$ less total tocopherols.

The results of our experiment show that the encapsulated rape, flax, and safflower seed oils had lower contents of bioactive compounds compared to the crude oils, regardless of the encapsulation method (spray- or freeze-drying). However, the degradation rate of the studied components is comparable to losses occurring in crude plant oils during culinary processes. Our results suggest that detailed analy- sis of oil composition is necessary before the encapsulation process to enable the appropriate choice of the components of wall materials and drying parameters.

\section{CONFLICTS OF INTEREST}

The authors declare no conflict of interest.

\section{RESEARCH FUNDING}

Project financially supported by Minister of Science and Higher Education in the range of the program entitled "Regional Initiative of Excellence" for the years 2019-2022, Project No. 010/RID/2018/19, amount of funding 12.000.000 PLN.

\section{REFERENCES}

1. Aghbashlo, M., Mobli, H., Madadlou, A., Rafiee, S. (2013). Influence of wall material and inlet drying air temperature on the microencapsulation of fish oil by spray drying. Food and Bioprocess Technology, 6(6), 1561-1569.

2. Aksoylu, Z., Günç Ergönül, P. (2017). A review on encapsulation of oils. Celal Bayar Üniversitesi Fen Bilimleri Dergisi, 13(2), 293-309.

3. Anwar, S.H., Kunz, B. (2011). The influence of drying methods on the stabilization of fish oil microcapsules: Comparison of spray granulation, spray drying, and freeze drying. Journal of Food Engineering, 105(2), 367-378.

4. Azadmard-Damirchi, S., Habibi-Nodeh, F., Hesari, J., Nemati, M., Achachlouei, B.F. (2010). Effect of pretreatment with microwaves on oxidative stability and nutraceuticals content of oil from rapeseed. Food Chemistry, 121 (4), 1211-1215.

5. Badke, L.B., Silva, B.C.D., Carvalho-Jorge, A.R.D., Taher, D.M., Riegel-Vidotti, I.C., Marino, C.E.B. (2019). Synthesis and characterization of microalgae fatty acids or Aloe vera oil microcapsules. Polímeros, 29(3), art. no. e2019042.

6. Bakry, A.M., Abbas, Sh., Ali, B., Majeed, H., Abouelwafa, M.Y., Mousa, A., Liang, L. (2016). Microencapsulation of oils: A comprehensive review of benefits, techniques, and applications. Comprehensive Reviews in Food Science and Food Safety, 15(1), 143-182.

7. Barbosa, M.I.M.J., Borsarelli, C.D., Mercadante, A.Z. (2005). Light stability of spray-dried bixin encapsulated with different edible polysaccharide preparations. Food Research International, 38(8-9), 989-994.

8. Barroso, A.K.M., Pierucci, A.P.T.R., Freitas, S.P., Torres, A.G., Rocha-Leão, M.H.M. da. (2014). Oxidative stability and sensory evaluation of microencapsulated flaxseed oil. Journal of Microencapsulation, 31(2), 193-201.

9. Ben Moumen, A., Mansouri, F., Richard, G., Fauconnier, M.L., Sindic, M., Nabloussi, A., Elamrani, A., Serghini Caid, H. (2015). Variations in the phytosterol and tocopherol compositions and the oxidative stability in seed oils from four safflower (Carthamus tinctorius L.) varieties grown in north-eastern Morocco. International Journal of Food Science \& Technology, 50(10), 2264-2270.

10. Bozan, B., Temelli, F. (2008). Chemical composition and oxidative stability of flax, safflower and poppy seed and seed oils. Bioresource Technology, 99(14), 6354-6359. 
11. Calvo, P., Castaño, Á.L., Hernández, M.T., González-Gómez, D. (2011). Effects of microcapsule constitution on the quality of microencapsulated walnut oil. European Journal of Lipid Science and Technology, 113(10), 1273-1280.

12. Calvo, P., Castaño, Á.L., Lozano, M., González-Gómez, D. (2012). Influence of the microencapsulation on the quality parameters and shelf-life of extra-virgin olive oil encapsulated in the presence of BHT and different capsule wall components. Food Research International, 45(1), 256-261.

13. Calvo, P., Hernández, T., Lozano, M., González-Gómez, D. (2010). Microencapsulation of extra-virgin olive oil by spraydrying: Influence of wall material and olive quality. European Journal of Lipid Science and Technology, 112(8), 852-858.

14. Carneiro, H.C.F., Tonon, R.V, Grosso, C.R.F., Hubinger, M.D. (2013). Encapsulation efficiency and oxidative stability of flaxseed oil microencapsulated by spray drying using different combinations of wall materials. Journal of Food Engineering, 115(4), 443-451.

15. Chang, C., Varankovich, N., Nickerson, M.T. (2016). Microencapsulation of canola oil by lentil protein isolate-based wall materials. Food Chemistry, 212, 264-273.

16. Coupland, J.N., Zhu, Z., Wan, H., Mcclements, D.J., Nawar, W.W., Chinachoti, P. (1996). Droplet composition affects the rate of oxidation of emulsified ethyl linoleate. Journal of the American Oil Chemists' Society, 73(6), 795-901.

17. Czaplicki, S., Ogrodowska, D., Derewiaka, D., Tańska, M., Zadernowski, R. (2011). Bioactive compounds in unsaponifiable fraction of oils from unconventional sources. European Journal of Lipid Science and Technology, 113(12), 1456-1464.

18. Czaplicki, S., Tańska, M., Konopka, I.Z. (2016). Sea-buckthorn oil in vegetable oils stabilisation. Italian Journal of Food Science, 28(3), 412-425.

19. Donsì, F., Annunziata, M., Sessa, M., Ferrari, G. (2011). Nanoencapsulation of essential oils to enhance their antimicrobial activity in foods. LWT - Food Science and Technology, 44(9), 1908-1914.

20. Dorni, C., Sharma, P., Saikia, G., Longvah, T. (2018). Fatty acid profile of edible oils and fats consumed in India. Food Chemistry, 238, 9-15.

21. Gallardo, G., Guida, L., Martinez, V., López, M.C., Bernhardt, D., Blasco, R., Pedroza-Islas, R., Hermida, L.G. (2013). Microencapsulation of linseed oil by spray drying for functional food application. Food Research International, 52 (2), 473-482.

22. Gawrysiak-Witulska, M., Rudzińska, M., Siger, A., Bartkowiak-Broda, I. (2015). A high drying temperature causes degradation of sterols and tocopherols in yellow-seeded Brassica napus oils. European Journal of Lipid Science and Technology, 117(4), 483-490.

23. Ghazani, S.M., García-Llatas, G., Marangoni, A.G. (2014). Micronutrient content of cold-pressed, hot-pressed, solvent extracted and RBD canola oil: Implications for nutrition and quality. European Journal of Lipid Science and Technology, 116(4), 380-387.

24. Goyal, A., Sharma, V., Sihag, M.K., Tomar, S.K., Arora, S., Sabikhi, L., Singh, A.K. (2015). Development and physicochemical characterization of microencapsulated flaxseed oil powder: A functional ingredient for omega-3 fortification. Powder Technology, 286, 527-537.

25. Harper, C.R., Edwards, M.J., DeFilipis, A.P., Jacobson, T.A., (2006). Flaxseed oil increases the plasma concentrations of car- dioprotective (n-3) fatty acids in humans. The Journal of Nutrition, 136(1), 83-87.

26. Hasani, M., Hossein Elhami Rad, A., Mohammad Hosseini, M., Shahidi Noghabi, M. (2015). Physicochemical characteristic of microencapsulated fish oil by freeze-drying using different combinations of wall materials. Biosciences, Biotechnology Research Asia, 12 (Special-Edn2), 45-51.

27. Heinzelmann, K., Franke, K., Velasco, J., Márquez-Ruiz, G. (2000). Microencapsulation of fish oil by freeze-drying techniques and influence of process parameters on oxidative stability during storage. European Food Research and Technology, 211 (4), 234-239.

28. Hernández Sánchez, M. del R., Cuvelier, M.E., Turchiuli, C. (2016). Effect of $\alpha$-tocopherol on oxidative stability of oil during spray drying and storage of dried emulsions. Food Research International, 88, 32-41.

29. Hogan, S.A., O'Riordan, E.D., O’Sullivan, M. (2003). Microencapsulation and oxidative stability of spray-dried fish oil emulsions. Journal of Microencapsulation, 20(5), 675-688.

30. Hue, W.L., Nyam, K.L. (2018). Physiochemical properties of kenaf seed oil microcapsules before and after freeze drying and its storage stability. International Food Research Journal, 25(4), 1502-1509.

31. Karaca, A.C., Nickerson, M., Low, N.H. (2013). Microcapsule production employing chickpea or lentil protein isolates and maltodextrin: Physicochemical properties and oxidative protection of encapsulated flaxseed oil. Food Chemistry, 139(1-4), 448-457.

32. Kaushik, P., Dowling, K., Barrow, C.J., Adhikari, B. (2015). Microencapsulation of omega-3 fatty acids: A review of microencapsulation and characterization methods. Journal of Functional Foods, 19, 868-881.

33. Khalid, N., Khan, R.S., Hussain, M.I., Farooq, M., Ahmad, A., Ahmed, I. (2017). A comprehensive characterisation of safflower oil for its potential applications as a bioactive food ingredient A review. Trends in Food Science \& Technology, 66, 176-186.

34. Khattab, R.Y., Zeitoun, M.A. (2013). Quality evaluation of flaxseed oil obtained by different extraction techniques. LWT - Food Science and Technology, 53(1), 338-345.

35. Kim, S.M., Chung, H.J., Lim, S.T. (2014). Effect of various heat treatments on rancidity and some bioactive compounds of rice bran. Journal of Cereal Science, 60(1), 243-248.

36. Kraljić, K., Škevin, D., Pospišil, M., Obranović, M., Neđeral, S., Bosolt, T. (2013). Quality of rapeseed oil produced by conditioning seeds at modest temperatures. Journal of the American Oil Chemists'Society, 90(4), 589-599.

37. Kwon, Y.J., Lee, K.T., Yun, T.M., Choi, S.W. (2004). Effect of heat pretreatment on the functional constituents of rice germ. Preventive Nutrition and Food Science, 9(4), 330-335.

38. Lewinska, A., Zebrowski, J., Duda, M., Gorka, A., Wnuk, M. (2015). Fatty acid profile and biological activities of linseed and rapeseed oils. Molecules, 20(12), 22872-22880.

39. Lindenstruth, K., Müller, B.W. (2004). W/O/W multiple emulsions with diclofenac sodium. European Journal of Pharmaceutics and Biopharmaceutics, 58(3), 621-627.

40. Miele, M., Murdoch, J. (2002). The practical aesthetics of traditional cuisines: slow food in Tuscany. Sociologia Ruralis, 42(4), 312-328.

41. Mikulcová, V., Kašpárková, V., Humpolíček, P., Buňková, L. (2017). Formulation, characterization and properties of hemp seed oil and its emulsions. Molecules, 22(5), 700. 
42. Nguemeni, C., Delplanque, B., Rovère, C., Simon-Rousseau, N., Gandin, C., Agnani, G., Nahon, J.L., Heurteaux, C., Blondeau, N. (2010). Dietary supplementation of alpha-linolenic acid in an enriched rapeseed oil diet protects from stroke. Pharmacological Research, 61(3), 226-233.

43. Nogala-Kałucka, M., Rudzińska, M., Zadernowski, R., Siger, A., Krzyzostaniak, I. (2010). Phytochemical content and antioxidant properties of seeds of unconventional oil plants. Journal of the American Oil Chemists' Society, 87(12), 1481-1487.

44. Ogrodowska, D., Tańska, M., Brandt, W. (2017). The influence of drying process conditions on the physical properties, bioactive compounds and stability of encapsulated pumpkin seed oil. Food and Bioprocess Technology, 10(7), 1265-1280.

45. Ogrodowska, D., Tańska, M., Brandt, W., Czaplicki, S. (2019). The influence of emulsion drying on the fatty acid composition, bioactive compounds content and oxidative stability of encapsulated bio-oils. CyTA - Journal of Food, 17(1), 949-959.

46. Quispe-Condori, S., Saldaña, M.D.A., Temelli, F. (2011). Microencapsulation of flax oil with zein using spray and freeze drying. LWT - Food Science and Technology, 44(9), 1880-1887.

47. Roszkowska, B., Tańska, M., Czaplicki, S., Konopka, I. (2015). Variation in the composition and oxidative stability of commercial rapeseed oils during their shelf life. European Journal of Lipid Science and Technology, 117(5), 673-683.

48. Rubilar, M., Morales, E., Contreras, K., Ceballos, C., Acevedo, F., Villarroel, M., Shene, C. (2012). Development of a soup powder enriched with microencapsulated linseed oil as a source of omega-3 fatty acids. European Journal of Lipid Science and Technology, 114(4), 423-433.

49. Rudzińska, M., Przybylski, R., Wąsowicz, E. (2009). Products formed during thermo-oxidative degradation of phytosterols. Journal of the American Oil Chemists' Society, 86(7), 651-662.

50. Ruiz Ruiz, J.C., Ortiz Vazquez, E.D.L.L., Segura Campos, M.R. (2017). Encapsulation of vegetable oils as source of omega-3 fatty acids for enriched functional foods. Critical Reviews in Food Science and Nutrition, 57(7), 1423-1434.

51. Shivakumar, K.M., Chetana, R., Reddy, S.Y. (2012). Preparation and properties of encapsulated fat powders containing speciality fat and $\omega /$ Pufa-rich oils. International Journal of Food Properties, 15(2), 412-425.
52. Silva, E.K., Zabot, G.L., Bargas, M.A., Meireles, M.A.A. (2016). Microencapsulation of lipophilic bioactive compounds using prebiotic carbohydrates: Effect of the degree of inulin polymerization. Carbohydrate Polymers, 152, 775-783.

53. Soupas, L., Huikko, L., Lampi, A.M., Piironen, V. (2006). Oxidative stability of phytosterols in some food applications. European Food Research and Technology, 222(3-4), 266-273.

54. Tańska, M., Roszkowska, B., Skrajda, M., Dąbrowski, G. (2016). Commercial cold pressed flaxseed oils quality and oxidative stability at the beginning and the end of their shelf life. Journal of Oleo Science, 65(2), 111-121.

55. Timilsena, Y.P., Wang, B., Adhikari, R., Adhikari, B. (2017). Advances in microencapsulation of polyunsaturated fatty acids (PUFAs)-rich plant oils using complex coacervation: A review. Food Hydrocolloids, 69, 369-381.

56. Tonon, R.V., Pedro, R.B., Grosso, C.R.F., Hubinger, M.D. (2012). Microencapsulation of flaxseed oil by spray drying: effect of oil load and type of wall material. Drying Technology, 30(13), 1491-1501.

57. Umesha, S.S., Monahar, B., Naidu, K.A. (2013). Microencapsulation of $\alpha$-linolenic acid-rich garden cress seed oil: Physical characteristics and oxidative stability. European Journal of Lipid Science and Technology, 115(12), 1474-1482.

58. Wang, R., Tian, Z., Chen, L. (2011). A novel process for microencapsulation of fish oil with barley protein. Food Research International, 44(9), 2735-2741.

59. Wang, S., Shi, Y., Han, L. (2018). Development and evaluation of microencapsulated peony seed oil prepared by spray drying: Oxidative stability and its release behavior during in-vitro digestion. Journal of Food Engineering, 231, 1-9.

60. Yalcin, H., Toker, O.S., Dogan, M. (2012). Effect of oil type and fatty acid composition on dynamic and steady shear rheology of vegetable oils. Journal of Oleo Science, 61 (4), 181-187.

61. Zadernowski, R., Sosulski, F. (1978). Composition of total lipids in rapeseed. Journal of the American Oil Chemists' Society, 55(12), 870-872.

62. Zhang, Z., Liu, Y., Che, L. (2018). Effects of different drying methods on the extraction rate and qualities of oils from demucilaged flaxseed. Drying Technology, 36(13), 1642-1652.

Submitted: 29 October 2019. Revised: 18 February and 3 April 2020. Accepted: 9 April 2020. Published on-line: 9 June 2020. 